\title{
A DESCRIPTION OF PERINATAL AS A RISK FACTOR OF CHILDREN'S SENSORINEURAL HEARING DISORDER IN OTOLARYNGOLOGY (ENT) POLYCLINIC OF ABDUL WAHAB HOSPITAL SJAHRANIE IN SAMARINDA
}

\author{
Inna Adilah ${ }^{1}$, Moriko Pratiningrum ${ }^{2}$, Marwan $^{3}$
}

\begin{abstract}
${ }^{1}$ Medical Education Study Program, School of Medicine, Mulawarman University, Indonesia
${ }^{2}$ Laboratory of Otolaryngology, School of Medicine, Mulawarman University, Indonesia

${ }^{3}$ Laboratory of Internal Medicine, School of Medicine, Mulawarman University, Indonesia
\end{abstract}

*E-mail: innaadilah@gmail.com

\begin{abstract}
Sensorineural Hearing Disorder in children could give a significant impact on everyday life and would cause loneliness, isolation, and frustration on children. Perinatal risk factors are important to note because they could be detected from newborn and could be an indication for the baby to do the screening. The purpose of hearing screening in newborns is to find hearing loss as early as possible so that habilitation can be done immediately. The purpose of this study was to describe perinatal period as risk factors for Sensorineural Hearing Disorder in children. The subjects of this study were children who has done BERA examinations at the Otolaryngology (ENT) Polyclinic of Abdul Wahab Sjahranie Hospital in Samarinda from January 2017 - June 2019. The design of this study was observational descriptive with cross-sectional method. There were 65 children as sample which consisted of $39(60 \%)$ boys and $26(40 \%)$ girls. BERA examination age that was found in this study has not reached the optimal standard if it is referring to the JCIH standard with the most age group is 3 years old. 37 (56.9\%) children suffered from Sensorineural Hearing Disorder. 27 (41.5\%) children had perinatal risk factors. The most common risk factors was jaundice which the researchers found on $11(16.9 \%)$ children. $20(30.8 \%)$ children who have perinatal risk factors and Sensorineural Hearing Disorder with the most common risk factor is LBW are as many as $10(15.4 \%)$.
\end{abstract}

Keywords: Sensorineural Hearing Disorder, perinatal period, risk factors

\section{INTRODUCTION}

Sensorineural Hearing Disorder in children could have a significant impact on daily life and would cause loneliness, isolation, and frustration on children. This would also have an impact on patient productivity and living costs. According to 2007 World Health Organization (WHO) data, the prevalence of hearing loss in the Indonesian population was estimated at $4.2 \%$ or around 9.3 million residents. In 2018, the WHO said there were 466 million people in the world suffering from hearing loss of which 34 million were children ${ }^{1}$.

Hearing loss has no clinical manifestations that appear on the physical sufferer. Newborns who experience hearing loss look normal, can even reach the stage of babbling, so it is not easy to detect ${ }^{2}$. Generally, parents are only aware of hearing loss in children when the children have no response to loud noise, having speech delay or unable to speak. The Joint Committee on Infant Hearing (JCIH) in 2007 recommended screening all infants who had a risk factor at least once at the age of 24 to 30 months ${ }^{3}$. 
Hearing loss in infants can be caused by a disturbance in the perinatal period. Risk factors obtained during the perinatal period itself can be low birth weight (LBW), jaundice, premature birth and asphyxia. These four conditions have an important influence on auditory function in early infancy. Perinatal risk factors are important to note because they can be detected from newborn and can be an indication for the baby to do a screening. The purpose of hearing screening in newborns is to detect hearing loss as early as possible so that habilitation can be done immediately ${ }^{4,5}$. Brainstem Evoked Response Audiometry (BERA) is an effective and non-invasive way to assess the functional status of the auditory nerve and brain stem sensory auditory pathways. BERA has a sensitivity of $100 \%$ and a specificity of $91 \% 6$.

Based on the background above, researchers were interested in examining the perinatal period as a risk factor for Sensorineural Hearing Disorder in children at the Otolaryngology (ENT) Polyclinic of Abdul Wahab Sjahranie Hospital in Samarinda.

\section{MATERIAL AND METHOD}

This was a descriptive study with a cross-sectional method. The sample of this study was all pediatric patients who performed ABA examination at the Otolaryngology (ENT) Polyclinic of Abdul Wahab Sjahranie Hospital in Samarinda in January 2017 - June 2019 that met the criteria. The data were primary data from interviews with parents/guardians of patients as interviewees and secondary data were from patient medical records. This research used purposive sampling. The inclusion criteria in this study was the age between $0-12$ years. Exclusion criteria were the patient who had a history of risk factors during the prenatal or postnatal period and the subject medical record was incomplete. The variables of this study were Sensorineural Hearing Disorder, LBW, premature birth, neonatal jaundice, and asphyxia. This research was conducted at Otolaryngology (ENT) Polyclinic of Abdul Wahab Sjahranie Hospital in Samarinda from August to September 2019. Data was tabulated using the Microsoft Office Excel 2019. The presentation of the data was displayed in tabular and narrative forms.

\section{RESULTS AND DISCUSSION}

In this study, researchers got 65 subjects out of 129 children. Based on the age of the child at the time of examination in Table 1, the samples mostly were 3 years as many as $17(26.2 \%)$ children. The oldest was 7 years with $4(6.2 \%)$ children, while the youngest was 0 years, $1(1.5 \%)$ children. The age of examination obtained in this study has not reached the optimal standard when referring to the $\mathrm{JCIH}$ standard. According to the JCIH standard, hearing loss in children must be detected at less than 3 months of age and carried out habilitation before the age of 6 months ${ }^{3}$.

Table 1. Characteristics of Samples by Children's Age at Examination

\begin{tabular}{ccc}
\hline $\begin{array}{c}\text { Age } \\
\text { (Year) }\end{array}$ & Total & $\begin{array}{c}\text { Percentage } \\
\text { (\%) }\end{array}$ \\
\hline 0 & 1 & 1.5 \\
1 & 6 & 9.2 \\
2 & 16 & 24.6 \\
3 & 17 & 26.2 \\
4 & 12 & 18.5 \\
5 & 5 & 7.7 \\
6 & 4 & 6.2 \\
7 & 4 & 6.2 \\
\hline Total & 65 & 100
\end{tabular}

Based on Table 2, the number of girl experiencing Sensorineural Hearing Disorder is higher than the boys, which is $21(32.3 \%)$ children. This is in line with the research of Bambang and Asti 
(2014) who found that girl experienced more Sensorineural Hearing Disorder than boy ${ }^{7}$. The influence of certain gender on hearing loss is related to $\mathrm{x}$-linked genetic factors, depending on the genetic factors of parents ${ }^{8}$.

Table 2. Sample Characteristics

\begin{tabular}{lccc}
\hline \multirow{2}{*}{ Risk Factors } & \multicolumn{2}{c}{ Sensorineural Hearing Disorder } & Total \\
\cline { 2 - 4 } Gender & Yes (N: 37) & No (N: 28) & \\
Boy & $16(24.6 \%)$ & $23(35.4 \%)$ & $39(60 \%)$ \\
Girl & $21(32.3 \%)$ & $5(7.7 \%)$ & $26(40 \%)$ \\
Perinatal Period & $20(30.8 \%)$ & $7(10.8 \%)$ & $27(41.5 \%)$ \\
Yes & $17(26.1 \%)$ & $21(32.3 \%)$ & $38(58.5 \%)$ \\
No & $10(15.4 \%)$ & & $10(15.4 \%)$ \\
LBW & $27(41.5 \%)$ & $0(0 \%)$ & $55(84.6 \%)$ \\
Yes & $2(3.1 \%)$ & $28(43.1 \%)$ & $5(7.7 \%)$ \\
No & $35(53.8 \%)$ & $3(4.6 \%)$ & $60(92.3 \%)$ \\
Premature & & $25(38.5 \%)$ & $11(16.9 \%)$ \\
Yes & $9(13.8 \%)$ & $2(3.1 \%)$ & $54(83.1 \%)$ \\
No & $28(43.1 \%)$ & $26(40 \%)$ & $8(12.3 \%)$ \\
Neonatal Jaundice & & & $57(87.7 \%)$ \\
Yes & $6(9.2 \%)$ & $2(3.1 \%)$ & \\
No & $31(47.7 \%)$ & $26(40 \%)$ & \\
Asphyxia & &
\end{tabular}

Characteristics of the sample based on risk factors in the perinatal period are determined by samples that have at least one of the factors such as LBW, premature, neonatal jaundice, asphyxia, or trauma during labour. Historical data on this risk factor was taken from interviews. The interviewees were parents/guardians of the sample who met the sample criteria.

The total number of samples with perinatal risk factors was $27(41.5 \%)$ children. The most common risk factor for all subjects was neonatal jaundice as many as $11(16.9 \%)$ children. The number of subjects who had perinatal risk factors and experienced sensorineural hearing disorder were $20(30.8 \%)$ children. The most common risk factor for children with sensorineural hearing disorder was LBW experienced by $10(15.4 \%)$ children.

In LBW, the patient might experience hypoglycaemia, hypernatremia, asphyxia and hypoxia which have an impact on various vital organs and organs of Corti and it can cause disruption of hair cell function in the cochlea ${ }^{4}$. Low birth weight also indicates that intrauterine fetal development cannot occur optimally. This affects the development of intrauterine and central nervous system. Premature birth and LBW have factors that are difficult to distinguish, so these two factors are closely related ${ }^{9}$.

Neonatal jaundice is a clinical manifestation of high levels of bilirubin in the blood or so-called hyperbilirubinemia. Hyperbilirubinemia is neurotoxic because the bilirubin can cross the blood barrier and is deposited in the ventrococlear nuke, then manifests as sensorineural hearing disorder ${ }^{10,11}$. Newborns with indirect bilirubin levels 亩 $20 \mathrm{mg} / \mathrm{dL}$ have a risk of experiencing sensorineural hearing disorder ${ }^{12}$.

The brain is more susceptible to anoxia than the ear and both are more at risk of damage after prolonged, pre-, peri- and post-natal hypoxia than pure hypoxia during birth labor ${ }^{12}$. Asphyxia can cause inner hair cell hyperpolarization which can reduce the amount of transmitter release resulting in decreased nerve activity. In addition, asphyxia can also cause an increase in glutamate and disruption of the apoptotic process. If it occurs in the auditory nerve, it can cause hearing disorder ${ }^{14}$. 


\section{CONCLUSION}

The conclusion of this research is according to BERA examination, the age obtained in this study has not reached the optimal standard if it is referring to the JCIH standard with the most age group is 3 years old. 37 (56.9\%) children suffered from Sensorineural Hearing Disorder. 27 (41.5\%) children had perinatal risk factors. The most common risk factors was jaundice which the researchers found on $11(16.9 \%)$ children. $20(30.8 \%)$ children who have perinatal risk factors and Sensorineural Hearing Disorder with the most common risk factor is LBW are as many as $10(15.4 \%)$.

\section{REFERENCE}

1. https://www.who.int/en/news-room/fact-sheets/detail/deafness-and-hearing-loss

2. Biswas AK, Goswami SC, Baruah DK, Tripathy R. The Potential Risk Factors and the Identification of Hearing Loss in Infants. Indian Journal Otolaryngol and Head \& Neck Surgery, p. 214-217 (2012).

3. Joint Committee on Infant Hearing. Executive summary of joint committe on infant hearing year 2007 position statement: Principles and guidelines for early hearing detection and intervention programs (2007).

4. Suwento R, Zizlavsky S, Hendarmin H. 2012. Gangguan Pendengaran Pada Bayi dan Anak. Buku Ajar Ilmu Kesehatan Telinga Hidung Tenggorok Kepala dan Leher. Edisi ke-7. Jakarta. FK UI. p. 33-35.

5. Lang-Roth R. Hearing Impairment and Language Delay in Infants: Diagnostics and Genetics. 2014.

6. Bhatt J, Chhangte L. Accuracy of OAE and BERA to Detect the Incidence of Hearing Loss in Newborn. International Journal of Scientific and Research Publications, p. 1-6 (2015).

7. Susyanto BE, Widuri A. Faktor Risiko Gangguan Pendengaran pada Skrining Pendengaran Bayi Baru Lahir di Rumah Sakit PKU Muhammadiyah Yogyakarta. Mutiara Medika, p. 30-36 (2015).

8. Corvino V, Apisa P, Malesci R, Laria C, Auletta G, Franze A. X-Linked Sensorineural Hearing Loss: A Literature Review. Current Genomics, p. 321-338 (2018).

9. Marlow E, Hunt L, Marlow N. Sensorineural hearing loss and prematurity. Arch Dis Child Fetal Neonatal, p. 141 (2000).

10. Mishra S, Agarwal R, Deoari A, Paul V. Jaundice in newborns. Indian J Pediatrics, p. 157 (2008).

11. Deborah L, Hilary L. 2001. Pediatric audiology. Head and Neck Surgery-Otolaryngology. Texas. Lippincott Williams \& Wilkins, p. 115-123.

12. Brad A, Stach, Viriginia S, Ramachandran. 2008. Hearing Disorders in Children. Pediatric Audiology. New York. Thieme Medical Publishers, p. 3-10.

13. Rahman S, Hanifatryevi. Asfiksia perinatal sebagai faktor resiko gangguan pendengaran pada anak. Padang. Universitas Andalas, (2012). 